\title{
Study about Swelling Behaviour of Black Cotton Soil with Fly Ash
}

\author{
Rajendra Prasad Hardaha ${ }^{1}$, Mohan Lal Agrawal ${ }^{2}$, Anita Agrawal ${ }^{3}$ \\ ${ }^{1}$ Research Scholar, Dr. C. V. Raman University Bilaspur (C.G.) and Assistant Professor, Rungta College of Engineering \&Technology, \\ Raipur-492099 (C.G.), India. \\ ${ }^{2}$ Professor Civil Engineering and Principal J.K. Institute of Engineering, Bilaspur(C.G.),India \\ ${ }^{3}$ Associate Professor and Head, Chemistry,J.K. Institute of Engineering, Bilaspur(C.G.),India
}

\begin{abstract}
Black Cotton soil is good for agriculture purpose but dangerous for construction point of view. In the region of Black Cotton soil (or say Expansive soil), swell-shrink behaviour is risky for the structure. In this research, fly ash has been used to stabilize the soil so that its swelling behaviour may control and becomes very small. Fly ash is the fine residue obtained from the thermal power stations using pulverised coal as boiler fuel. It poses the dual problem of disposal and environmental pollution and hence generally treated as waste. The present paper deals with the evaluation of Free swell index of black cotton soil with fly ash, which are individually determined first and then combined in varying proportions. From Preliminary investigations it can be said that free swelling index can be reduced in Black Cotton soil by the use of fly ash.
\end{abstract}

Keywords: Fly ash, Black cotton soil, Swelling behaviour, Free Swelling Index.

\section{Introduction}

For construction of any structure, first of all,the designer requires the data about soil classification, characteristics and its behaviour in different situations/conditions. It is most necessary when the soil is expansive soil or Black Cotton soil because their swells-shrink behaviour. From mineralogical analysis, rich proportion of montmorillonite is found in Black cotton soil. High percentage of montmorillonite renders high degree of expansiveness. These property results cracks in soil without any warning. These cracks may sometimes extent to severe limit like $1 / 2$ " wide and 12" deep. So building to be founded on this soil may suffer severe damage with the change of atmospheric conditions.

Black cotton soils are inorganic clays of medium to high compressibility and form a major soil group in India. They are characterized by high shrinkage and swelling properties. This Black cotton soils occurs mostly in the central and western parts and covers approximately $20 \%$ of the total area of India. Because of its high swelling and shrinkage characteristics, the Black cotton soil (BC soils) has been a challenge to the highway engineers. The Black cotton soil is very hard when dry, but loses its strength completely when in wet condition. As a result of wetting and drying process, vertical movement takes place in the soil mass. All thesemovements lead to failure of pavement, in the form of settlement, heavy depression, cracking and unevenness.

In such situations, improvement of soil properties has been widely used for resolving the site condition. Utilization of fly ash is a better solution as per Govt. rules sand reduces waste material to save the environment. The Indian coal is of low grade having high ash content of the order of $30-45 \%$ generating large quantity of fly ash at coal/lignite based thermal power stations in the country. The management of fly ash has thus been a matter of concern in view of requirement of large area of land for its disposal because of its potential of causing pollution of air and water. A large number of technologies have been developed for gainful utilization and safe management of fly ash under the concerted efforts made by fly Ash Mission/Fly Ash Unit under Ministry of Science \& Technology, Government of India since 1994. As a result, Fly ash earlier considered to be "hazardous industrial waste" material, has now acquired the status of useful and saleable commodity. ${ }^{(1)}$

In view of the above an attempt has been made to utilize the fly ash in different proportions $(10 \%, 20 \%, 30 \%, 40 \%$ and $50 \%$ ) by weight with Black cotton soil and the modifications in its geotechnical behaviour was evaluated.

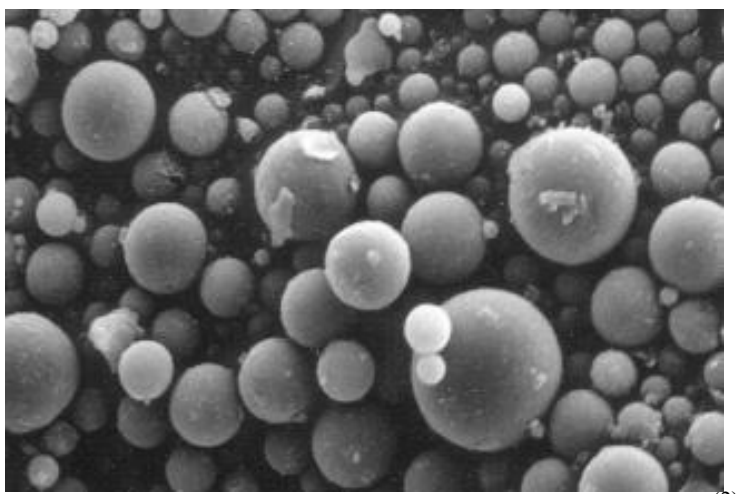

Figure 1: Fly ash particles at 2,000x magnification

\section{Literature Review}

Many work in this regard have been done by the researchers, some of them are as follows:

PriyankGoyalet. al. ${ }^{(3)}$ present in his paper is an attempt to study the effectiveness of coconut fibre (coir) to control swelling properties of black cotton soil along with an impact on its strength characteristics and dry density. The test results show that in presence of $2 \%$ coir fibre, the shrinkage limit is 


\section{International Journal of Science and Research (IJSR) \\ ISSN (Online): 2319-7064 \\ Index Copernicus Value (2013): 6.14 | Impact Factor (2014): 5.611}

increases by $7.52 \%$ to $12.62 \%$. Increase in compressive strength was observed from 1.09 to $1.32 \mathrm{~kg}$ per sq-cm.

Aparnaet.al., ${ }^{(4)}$ In this paper presents the result of an experimental study conducted for evaluating the effect of size of the sand column on swelling of expansive soil. The sand columns of diameters $25 \mathrm{~mm}, 37.5 \mathrm{~mm}$ and $50 \mathrm{~mm}$ were made in black cotton soil test beds in a cylindrical mould of diameter $100 \mathrm{~mm}$. The test beds were prepared at different water contents $(14,18,22,26,30,36,40$ and $44 \%$ by weight of dry soil) keeping the dry density of the soil as constant. The soil with sand column was submerged and the swelling of the composite material was observed. The test results show that the presence of sand column in the expansive black cotton soil reduces the swelling.

Stephen George Emmanuel et.al., ${ }^{(5)}$ In his study, soil has been tested for its swelling behaviour. To stabilize the soil so that its swelling behaviour reduces and becomes very small, fly ash has been used. This fly ash has been added to the soil in different ratios as a partial substitute and the swelling behaviour of each sample has been tested. Results have shown that in with the increase of fly ash content, the swelling behaviour has been noticed to decrease.

Brajesh Mishra, ${ }^{(6)}$ In his study conducted on the basis of experimental investigations it was observed that the property of black cotton soil effectively improved by use of different percentage of lime contents. In this research varying percentage $(3 \%$ and $5 \%)$ of lime was used to stabilize the black cotton soil.

S. Lhamu et.al., ${ }^{(7)}$ In this paper the swelling behaviour of expansive soil stabilized with different proportion of fly ash content (i.e $0 \%, 10 \%, 20 \%, 40 \%, 60 \%$ and $80 \%$ ) has been investigated through a series of experiments. The test results indicate that addition of fly ash to expansive soils reduces the free swell index, swell potential and swell pressure.

Sarat Kumar Das et.al., ${ }^{(8)}$ presents the paper for stabilization of a local expansive soil using alkali activated fly ash. The activated fly ash at different alkali concentrations and potassium hydro oxide and fly ash ratios were also tested. Different geotechnical properties like Atterberg's limits, compaction and strength behaviour of stabilized expansive soil were tested. It was observed that there is a considerable improvement in geotechnical properties of expansive soil with the addition of alkali activated fly ash.

G Radhakrishnan et.al., ${ }^{(9)}$ Works with the objective to study the swelling properties of the expansive sub grade soil treated with chemicals like Magnesium Chloride $(\mathrm{MgCl} 2)$, Aluminium Chloride ( $\mathrm{AlCl} 3$ ) and also by adding fly ash in varying percentages. The swelling properties of the collected expansive soil samples were determined based on the parameters like Free Swell Index, Swell Potential and Swell Pressure. The results obtained from the experimental study indicate that the measured Free Swell, Swell Potential and Swelling Pressure are reduced substantially with the increasing percent of chemicals and flyash and remain stable after reaching certain concentration.
Saeid.Amiralian et.al., ${ }^{(10)}$ Presents a series of laboratory tests for investigation on the adequacy of fly ash on the compressibility and swelling characteristic of soil. In this research the compression index, swelling index, and initial void ratio of one un-stabilized sample and eight stabilized specimens with difference fly ash additives were investigated. Overall, the data reveal that fly ash stabilization could reduce the consolidation property, swelling behaviour. In addition, increment in the amount of fly ash led to reduction in the initial void ratio of stabilized samples.

PratimaKumari et.al., ${ }^{(11)}$ In her paper presents influence of Lime and Fly ash on various tests conducted such as Free Swell Index (FSI), Swelling Pressure, Compaction Characteristics, Liquid Limit ,Plastic Limit ,Plasticity Index . The result obtained from experimental study indicates that the Free Swell Index and swelling pressure were reduced regularly with increasing percentage of Lime and Fly ash.

\section{Test Materials}

\subsection{Black Cotton Soil}

Soil used for this investigation is collected from a depth of $1.5 \mathrm{~m}$ below the ground level from Raipur, Chhattisgarh, India.

Table 1: Characteristics of Black cotton soil

\begin{tabular}{|c|c|c|}
\hline S. No. & Property & Value \\
\hline 1 & Dry density $(\gamma d)$ & $1300-1800 \mathrm{Kg} / \mathrm{m}^{3}$ \\
\hline 2 & Liquid Limit (L.L.) & $40-120 \%$ \\
\hline 3 & Plastic Limit (P.L.) & $20-60 \%$ \\
\hline 4 & Activity & $0.8-18 \%$ \\
\hline 5 & Specific Gravity(G) & $2.60-2.75$ \\
\hline 6 & Proctor Density & $1350-1600 \mathrm{Kg} / \mathrm{m}^{3}$ \\
\hline 7 & OMC ( Max dry density) & $20-35 \%$ \\
\hline 8 & Free Swell Index & $40-180 \%$ \\
\hline 9 & Swelling pressure & $50-800 \mathrm{KN} / \mathrm{m}^{2}$ \\
\hline 10 & C.B.R. (soaked) & $1.2-4.0$ \\
\hline 11 & Compression Index & $0.2-0.5$ \\
\hline 12 & Fines( $<75 \mu)$ & $70-100 \%$ \\
\hline 13 & $2 \mu$ Fraction & $20-60 \%$ \\
\hline 14 & Soil Classification & CH or $\mathrm{MH}$ \\
\hline
\end{tabular}

The properties of black cotton soil used for the study are shown in the table given below.

Table 2: Properties of black cotton soil

\begin{tabular}{|c|c|c|}
\hline S. No. & Property & Value \\
\hline 1 & Dry density $(\gamma \mathrm{d})$ & $1420 \mathrm{Kg} / \mathrm{m}^{3}$ \\
\hline 2 & Liquid Limit (L.L.) & $63 \%$ \\
\hline 3 & Plastic Limit (P.L.) & $27 \%$ \\
\hline 4 & Activity & $0.8-18 \%$ \\
\hline 5 & Specific Gravity(G) & 2.60 \\
\hline 6 & Proctor Density & $1587 \mathrm{Kg} / \mathrm{m}^{3}$ \\
\hline 7 & OMC ( Max dry density) & $22.5 \%$ \\
\hline 8 & Free Swell Index & $60 \%$ \\
\hline 9 & Swelling pressure & - \\
\hline 10 & C.B.R. (soaked) & $1.90 \%$ \\
\hline 11 & Compression Index & - \\
\hline 12 & Fines $(<75 \mu)$ & $86.6 \%$ \\
\hline 13 & $2 \mu$ Fraction & - \\
\hline 14 & Soil Classification & $\mathrm{CH}$ \\
\hline
\end{tabular}




\section{International Journal of Science and Research (IJSR) \\ ISSN (Online): 2319-7064}

Index Copernicus Value (2013): 6.14 | Impact Factor (2014): 5.611

\subsection{Fly ash}

Fly ash is finely divided residue resulting from the combustion of powdered coal,transported by the fuel gases and collected by electrostatic precipitator. When fly ash and bottom ash are mixed and disposed in the form of water slurry to ash ponds, it is called pond ash. For the purpose of embankment construction either pond ash, bottom ash or mound ash can be used. Fly ash being a very fine material is not recommended for embankment construction. ${ }^{(12)}$ In India the total production of fly ash is nearly as much as that of cement Fly ash used for the present study wasbrought from M/s. Sarda Energy, Siltara, Raipur (C.G.).

Table 3: Typical Geotechnical Properties of Pond ash ${ }^{(12)}$

\begin{tabular}{|c|c|c|}
\hline S. No. & Parameter & Range \\
\hline 1 & Specific Gravity & $1.90-2.55$ \\
\hline 2 & Plasticity & Non-Plastic \\
\hline 3 & Maximum Dry Density $(\mathrm{gm} / \mathrm{cc})$ & $0.9-1.6$ \\
\hline 4 & Optimum Moisture Content $(\%)$ & $38.0-18.0$ \\
\hline 5 & ${\text { Cohesion }\left(\mathrm{kN} / \mathrm{m}^{2}\right)}_{1}$ & Negligible \\
\hline 6 & Angle of Internal Friction $(\Phi)$ & $30^{0}-40^{0}$ \\
\hline 7 & Coefficient of Consolidation & $1.75 \times 10^{-5}-2.01 \mathrm{x}$ \\
& $\mathrm{C}_{\mathrm{v}}\left(\mathrm{cm}^{2} / \mathrm{sec}\right)$ & $10^{-3}$ \\
\hline 8 & ${\text { Compression Index } \mathrm{C}_{\mathrm{c}}}_{0.05-0.4}$ \\
\hline 9 & Permeability $(\mathrm{cm} / \mathrm{sec})$ & $8 \times 10^{-6}-7 \times 10^{-4}$ \\
\hline \multirow{2}{*}{10} & Particle Size Distribution $(\%$ of & \\
\cline { 2 - 3 } & material) & $1-10$ \\
\cline { 2 - 3 } & Clay size fraction & $8-85$ \\
\cline { 2 - 3 } & Silt size fraction & $7-90$ \\
\cline { 2 - 3 } & Sand size fraction & $0-10$ \\
\cline { 2 - 3 } & Gravel size fraction & $3.1-10.7$ \\
\hline \multirow{2}{*}{11} & Coefficient of Uniformity \\
\hline
\end{tabular}

Properties of Fly ash for the study are shown in the table given below.

Table 4: Geotechnical Properties of Fly Ash:

\begin{tabular}{|c|c|c|}
\hline S. No. & Parameter & Range \\
\hline 1 & Specific Gravity & 2.4 \\
\hline 2 & Plasticity & Non-Plastic \\
\hline 3 & Maximum Dry Density $(\mathrm{gm} / \mathrm{cc})$ & 1.2 \\
\hline 4 & Optimum Moisture Content $(\%)$ & 35 \\
\hline 5 & Cohesion $\left(\mathrm{kN} / \mathrm{m}^{2}\right)$ & Negligible \\
\hline 6 & Angle of Internal Friction $(\Phi)$ & $34^{0}$ \\
\hline 7 & Coefficient of Consolidation $\mathrm{C}_{\mathrm{v}}\left(\mathrm{cm}^{2} / \mathrm{sec}\right)$ & - \\
\hline 8 & Compression Index $\mathrm{C}_{\mathrm{c}}$ & - \\
\hline 9 & Permeability $(\mathrm{cm} / \mathrm{sec})$ & - \\
\hline 10 & Particle Size Distribution $(\%$ of material) & \\
\cline { 2 - 3 } & Clay size fraction & 0 \\
\cline { 2 - 3 } & Silt size fraction & 79 \\
\hline
\end{tabular}

\begin{tabular}{|c|c|c|}
\hline & Sand size fraction & 21 \\
\cline { 2 - 3 } & Gravel size fraction & 0 \\
\hline 11 & Coefficient of Uniformity & - \\
\hline
\end{tabular}

\subsection{Laboratory Tests On Soils, Fly Ash \&Their Mixtures:}

Soil-Fly Ash mixtures were prepared for Experimental investigation by mixing 10,20,30,40 and $50 \%$ of Fly ash (by weight). All these mixtures were tested in the laboratory as per procedure described in respective IS codes for Specific Gravity,Grain size distribution;Index properties and Free swell Index.

\section{Specific Gravity:}

Specific Gravity of Soil solids is the ratio of weight, in air of a given volume, of dry soil solids to the weight of equal volume of water at $4^{\circ} \mathrm{C}$. For determination of Sp.Gravity,Sample were tested as per IS 2720 Part-III.

\section{Grain Size Distribution:}

Grain size analysis is used in the engineering classification of soils. The percentage of various mass of particles in agiven dry soil sample is found by a particle-size analysis or mechanical analysis. Itwas determined as per IS: 2720 PartIV.

\section{Index Properties:}

Liquid limit and Plastic Limit of soil were determined as per IS: 2720 Part-V.

\section{Free Swell Index:}

The increase in volume as a percentage of initial volume of soil is referred as free swelling index of soil. IS; 2720 Part 40-1985.

\section{Test Results and Discussion}

Table 5: Grain Size Distribution

\begin{tabular}{|c|c|c|c|c|c|c|}
\hline S. No. & $\begin{array}{c}\text { Fly Ash } \\
\text { Content } \\
(\%)\end{array}$ & $\begin{array}{c}\text { Gravel } \\
(\%)\end{array}$ & $\begin{array}{c}\text { Coarse } \\
\text { Sand } \\
(\%)\end{array}$ & $\begin{array}{c}\text { Medium } \\
\text { Sand (\%) }\end{array}$ & $\begin{array}{c}\text { Fine } \\
\text { Sand } \\
(\%)\end{array}$ & $\begin{array}{c}\text { Silt \& } \\
\text { Clay } \\
(\%)\end{array}$ \\
\hline 1 & 0 & 4.80 & 1.40 & 2.80 & 4.40 & 86.60 \\
\hline 2 & 10 & 2.60 & 1.00 & 2.20 & 5.40 & 88.80 \\
\hline 3 & 20 & 1.80 & 1.00 & 2.20 & 6.20 & 88.80 \\
\hline 4 & 30 & 3.00 & 1.20 & 1.80 & 7.00 & 87.00 \\
\hline 5 & 40 & 1.00 & 0.80 & 2.20 & 9.20 & 86.80 \\
\hline 6 & 50 & 0.80 & 0.80 & 1.80 & 10.00 & 86.60 \\
\hline 7 & 100 & 0.00 & 0.00 & 0.00 & 21.0 & 79.00 \\
\hline
\end{tabular}

Table 6: Variation of Index Properties of Black Cotton Soil with Fly Ash Percentage.

\begin{tabular}{|c|c|c|c|c|c|c|c|}
\hline S. No. & $\begin{array}{c}\text { Fly Ash Content } \\
(\%)\end{array}$ & $\begin{array}{l}\text { Liquid Limit } \\
\qquad\left(\mathrm{W}_{\mathrm{L}}\right)\end{array}$ & $\begin{array}{c}\text { Plastic Limit } \\
\left(\mathrm{W}_{\mathrm{P}}\right)\end{array}$ & $\begin{array}{l}\text { Plasticity } \\
\text { Index }\left(\mathrm{I}_{\mathrm{P}}\right)\end{array}$ & $\begin{array}{l}\text { Liquidity } \\
\text { Index }\left(\mathrm{I}_{\mathrm{L}}\right)\end{array}$ & $\begin{array}{l}\text { Consistency } \\
\text { Index }\left(\mathrm{I}_{\mathrm{C}}\right)\end{array}$ & $\begin{array}{c}\text { Specific } \\
\text { Gravity }\left(\mathrm{G}_{\mathrm{S}}\right)\end{array}$ \\
\hline 1 & 0 & $62.5 \%$ & $27.0 \%$ & $35.5 \%$ & -0.61 & 1.61 & 2.60 \\
\hline 2 & 10 & $58.0 \%$ & $23.9 \%$ & $34.1 \%$ & -0.55 & 1.55 & 2.54 \\
\hline 3 & 20 & $59.0 \%$ & $25.7 \%$ & $33.3 \%$ & -0.62 & 1.62 & 2.51 \\
\hline 4 & 30 & $60.0 \%$ & $30.0 \%$ & $30.0 \%$ & -0.83 & 1.83 & 2.47 \\
\hline 5 & 40 & $61.5 \%$ & $31.0 \%$ & $30.5 \%$ & -0.85 & 1.85 & 2.45 \\
\hline 6 & 50 & $62.5 \%$ & $33.3 \%$ & $29.2 \%$ & -0.96 & 1.96 & 2.43 \\
\hline
\end{tabular}




\section{International Journal of Science and Research (IJSR) \\ ISSN (Online): 2319-7064}

Index Copernicus Value (2013): 6.14 | Impact Factor (2014): 5.611

Table 7: Free Swell Index

\begin{tabular}{|c|c|c|}
\hline S. No. & $\begin{array}{c}\text { Fly Ash Content } \\
(\%)\end{array}$ & $\begin{array}{c}\text { Free Swell Index } \\
(\%)\end{array}$ \\
\hline 1 & 0 & 66.6 \\
\hline 2 & 10 & 50.0 \\
\hline 3 & 20 & 33.3 \\
\hline 4 & 30 & 20.6 \\
\hline 5 & 40 & 9.10 \\
\hline 6 & 50 & 4.2 \\
\hline
\end{tabular}

Swelling and shrinkage of soil lead to distress in the substructure resulting in failure in foundation. Swelling of soils exerts upward pressure on the foundation. The amount of pressure exerted by the soil depends on the amount of increase in volume. Here we can see (Table 7) with addition of Fly ash, free swell index gradually decrease, means volume of soil reduces or in other words swelling behaviour can be controlled.

\section{P.I. and Their meaning: \\ 0-3 Non Plastic \\ 3-15 Slightly Plastic \\ 15-30 Medium Plastic \\ $>30 \quad$ High Plastic}

Plasticity Index increases with increase in clay content. With addition of Fly ash Plasticity Index can be reduced (Table 6) and soil sample converts from high plastic stage to medium plastic stage.On the basis of test results, above soil is classified as $\mathrm{CH}$ (High compressibility soils, liquid limit greater than 50) was changed to $\mathrm{MH}$.

The value of Sp. gravity helps in identifying and classifying the soil type. It gives an idea about the suitability of the soil as construction material. High value of Specific gravity indicates more compactness and gives more strength for roads and foundations.

\section{Conclusions}

On the basis of experimental investigations, it was observed that the properties of Black cotton soil can be improved by the use of fly ash. Some outcomes are as listed below:

On addition of Fly ash in black cotton soil, a free swell index decreasewhich indicates controls the swelling behaviour of soil. Hence minimise the risk of failure.

Plasticity Index decreases in addition of fly ash in Black cotton soil.Classification of soil change from $\mathrm{CH}$ to $\mathrm{MH}$, which indicates soil sample converts from high plastic stage to medium plastic stage.Due to improvement in its plasticity characteristics, Black cotton soil can be used for base courses by stabilizing with fly ash.

Utilization of Fly ashas an agent, for improving the engineering properties of soil, reduces the demand of land for its disposal and hence controls the source of pollution

In Chhattisgarh state, power production units producing fly ash containing very less quantity of lime called " $F$ " type fly ash having poor bonding and cementaceous property. Thus necessitating the requirement of some bonding agent,that's why the lime should be added to increase and develops well cementaceous materials.

\section{References}

[1] Central Electricity Authority," Report on Fly ash generation at coal/lignite based thermal power stations and its utilization in the country for the year 2014-15". New Delhi.

[2] Fly ash facts for Highway Engineers, Report No. FHWAIF-03-019, dt. 6/3/2003.

[3] PriyankGoyal, AshutoshShankerTrivedi and Manoj Sharma ,"Improvement in Properties of Black Cotton Soil with an Addition of Natural Fibre (Coir) Derived From Coconut Covering", Int. Journal of Engineering Research and Applications ,ISSN : 2248-9622, Vol. 5, Issue 3, ( Part -5) March 2015, pp.36-37

[4] Aparna, P.K. Jain, and RakeshKumar, "Study of Swelling Behaviour of Black Cotton Soil Improved with Sand Column", International Journal of Advances in Engineering \& Technology, July, 2014.,IJAET ISSN: 22311963, Vol. 7, Issue 3, pp. 905-910

[5] Stephen George Emmanuel, Yitendra Kumar Bind," A Study of the Swelling Behaviour of Soil Mixed with Different Ratios of Fly Ash as a Partial Substitute", International Journal of Research in Engineering Technology and Management ISSN 2347 - 7539, Volume: 02 Issue: $02 \mid$ Mar-2014, P.P. 1-2.

[6] Brajesh Mishra, "A Study on Engineering Behavior of Black Cotton Soil and its Stabilization by Use of Lime", International Journal of Science and Research (IJSR)ISSN (Online): 2319-7064, Volume 4 Issue 11, November 2015, p.p.290-294

[7] S. Lhamu and M. Hussain, "Swelling Behaviour of Fly Ash Stabilized Expansive Soil," Proceedings of Indian Geotechnical Conference, December 22-24,2013, Roorkee, p.p.1-8.

[8] Sarat Kumar Das and ParthaSarathiParhi ,"Stabilization of Expansive Soil Using Alkali Activated Fly Ash," Proceedings of Indian Geotechnical Conference December 22-24,2013, Roorkee,p.p. 1-4.

[9] G Radhakrishnan ,Dr M Anjan Kumar and Dr GVR PrasadaRaju, "Swelling Properties of Expansive Soils Treated with Chemicals and Flyash", American Journal of Engineering Research (AJER), e-ISSN : 2320-0847 p-ISSN : 2320-0936, Volume-03, Issue-04, pp-245-250

[10] Saeid. Amiralian, Amin. Chegenizadeh, and Hamid. Nikraz, "Laboratory Investigation on the Effect of Fly Ash on the Compressibility of Soil", International Conference on Civil and Architectural applications (ICCAA'2012) December 18-19, 2012 Phuket (Thailand),p.p. 84-88.

[11] PratimaKumari, ProffPrafulla Sharma and ProffJ.P.Singh, "Swelling Behaviour of Expansive Soil Mixed with Lime and Fly Ash as Admixture," International Journal of Innovative Research in Science, Engineering and Technology, ISSN(Online): 2319-8753,ISSN (Print): 23476710, Vol. 4, Issue 6, June 2015,p.p.4364-4372.

[12] Indian Road Congress, Special Publication 58, "Guidelines For Use of Fly Ash In Road Embankments", New Delhi 2001

[13] E Saibaba Reddy and K. Rama Sastri, "Measurement of Engineering Properties of Soils", New Age International Publishers, New Delhi. First edition 2002. 